\title{
Altered Density of Glomerular Binding Sites for Atrial Natriuretic Factor in Bile Duct-ligated Rats with Ascites
}

\author{
AleXander L. Gerbes, ${ }^{1}$ Margit C. Kollenda, ${ }^{1}$ ANgelika M. Vollmar, ${ }^{2}$ JÜrg Reichen, ${ }^{3}$ Nimish VaKIL ${ }^{4}$ \\ AND ROBERT M. SCARBOROUGH ${ }^{5}$ \\ ${ }^{1}$ Department of Medicine II, Klinikum Großhadern, 'Institute of Pharmacology, Toxicology and Pharmacy, \\ University of Munich, D-8000 München, FRG; ${ }^{3}$ Department of Clinical Pharmacology, University of Berne, CH-3010 Berne, \\ Switzerland; ${ }^{4}$ University of Rochester, Rochester, New York 14642; and ${ }^{5}$ Cor Therapeutics, Inc., South San Francisco, \\ California 94080
}

\begin{abstract}
The renal response to atrial natriuretic factor is blunted in cirrhosis with ascites. This might be due to alterations of renal receptors for atrial natriuretic factor. Therefore density and affinity of glomerular atrial natriuretic factor binding sites of bile ductligated rats with ascites $(n=10)$ and of sham-operated controls $(n=10)$ were determined. Glomerular atrial natriuretic factor binding sites were identified to be of the B-("biologically active") and C-("clearance") receptor type. Discrimination and quantitative determination of $B$ and $C$ receptors for atrial natriuretic factor were achieved by displacement experiments with atrial natriuretic factor(99-126) or des(18-22)atrial natriuretic factor(4-23), an analogue binding to $C$ receptors only. Density of total glomerular atrial natriuretic factor binding sites was significantly increased in bile duct-ligated rats $(3,518 \pm 864$ vs. $1,648 \pm 358 \mathrm{fmol} / \mathrm{mg}$ protein; $p<0.05)$. This was due to a significant increase of C-receptor density $(3,460 \pm$ 866 vs. $1,486 \pm 363 \mathrm{fmol} / \mathrm{mg}$ protein; $p<0.05$ ), whereas density of $B$ receptors was not significantly different in bile duct-ligated rats $(58 \pm 11$ vs. $162 \pm 63 \mathrm{fmol} / \mathrm{mg}$ protein). Affinity of atrial natriuretic factor to its glomerular binding sites did not differ significantly between both groups. These data suggest that an altered glomerular atrial natriuretic factor receptor density could be involved in the renal resistance to atrial natriuretic factor in cirrhosis with ascites. (HEPATOLOGY 1991;13:562-566.)
\end{abstract}

Received March 1, 1990; accepted September 20, 1990

This paper is dedicated to Professor Dr. W. Gerok in honor of his sixty-fifth birthday.

This work was supported by a grant from the Deutsche Forschungsgemeinschaft (GE 576).

Parts of this study were presented at the Fortieth Annual Meeting of the AASLD, October 28-31, 1989, Chicago, Illinois, and at the Twenty-fourth Annual Meeting of the EASL, August 30 - September 2, 1989, Munich, Germany. This work contains data that are part of a doctoral thesis by M.C. Kollenda at the Ludwig-Maximilianus-Universität, München.

Jürg Reichen was supported by SNF grant 32-9365.87.

Address reprint requests to: Alexander L. Gerbes, M.D., Med. Klinik II Klinikum Großhadern, University of Munich, Marchioninistr. 15, D-8000 München 70, FRG

$31 / 1 / 27000$
Atrial natriuretic factor (ANF) is a hormone intimately involved in the regulation of body fluid and electrolyte balance (1-5). ANF induces natriuresis and diuresis by interaction with specific renal receptors. Lately, the presence of two distinct ANF receptor types has been demonstrated: The $B$ and $C$ receptors $(6-9)$ : The $B$ receptor has a molecular weight of about $130 \mathrm{kD}$, exhibits a high affinity to circulating ANF and is considered to mediate the biological actions of ANF by activating particulate guanylate cyclase, which is part of its intracellular domain. It has thus been called "B" (for biologically active) receptor. The difference in structural requirements for binding of ANF ligands allows for quantitative discrimination from the $\mathrm{B}$ receptor. This binding site removes ANF from the circulation without inducing apparent biological actions and has thus been termed "C" (for clearance) receptor. The C receptor has a molecular weight of about $65 \mathrm{kD}$, binds circulating ANF with lower affinity but also binds truncated analogs of ANF.

Alterations of total glomerular ANF receptor density have been demonstrated after changes of body fluid volume (10-12). Recently, we have shown that physiological changes of body fluid volume affect density of both receptor subtypes on glomerular membranes to a different extent (13). Therefore it is important to discriminate between $\mathrm{B}$ and $\mathrm{C}$ receptors also when investigating the ANF receptor status in a pathophysiological state.

Renal response to ANF has been shown to be blunted in patients with cirrhosis and in rat models of cirrhosis (14-21). This renal resistance to circulating and to exogenously administered ANF in cirrhosis might be due to an alteration of ANF receptor density. Therefore in this study we investigated both types of ANF binding sites in renal glomeruli of cirrhotic rats.

\section{MATERIALS AND METHODS}

Animals. Male Sprague-Dawley rats (300 to $320 \mathrm{gm}$ ) were subjected to bile duct ligation and division (22). In the control group, animals were sham-operated with visualization of the bile duct. The rats were fed with regular pelleted chow and tap 
water. Approximately 6 wk after bile duct ligation, rats with evidence of ascites were decapitated, trunk blood was collected in precooled EDTA tubes $(1 \mathrm{mg} / \mathrm{ml})$ and the kidneys were rapidly excised. Ten bile duct-ligated (BDL) animals with ascites were compared with 10 sham-operated controls (SHAM).

RIA for $A N F$. Blood samples were centrifuged at $1,500 \mathrm{~g}$ for $10 \mathrm{~min}$ at $4^{\circ} \mathrm{C}$ and the plasma was stored at $-70^{\circ} \mathrm{C}$ until assay. Extraction of plasma samples and RIA procedures were modified from previously reported procedures $(17,23)$. Briefly, $200 \mu \mathrm{l}$ plasma samples were extracted by adsorption to activated Amberlite XAD-2 adsorbent resin (particle size 0.3 to $1.0 \mathrm{~mm}$, Serva, Heidelberg, FRG) and eluted with acetonitrile $/ 0.1 \%$ trifluoroacetic acid $(80 \% / 20 \%)$. Recovery was $70 \%$ and the detection limit of the RIA was $0.5 \mathrm{fmol} / \mathrm{tube}$.

Preparation of Glomerular Membranes. Rat glomeruli were isolated according to a graded sieving method (24) with some modifications. Kidneys were cut longitudinally, the medulla was removed and the cortical tissue was filtered through $250 \mu \mathrm{m}, 140 \mu \mathrm{m}$ and $75 \mu \mathrm{m}$ sieves. Glomeruli were then suspended in ice-cold PBS, pH 7.5, and centrifuged $(10,000 \mathrm{~g}$, $4^{\circ} \mathrm{C}, 10 \mathrm{~min}$ ). Membranes were prepared by resuspending the glomeruli in $50 \mathrm{mmol} / \mathrm{L}$ Tris- $\mathrm{HCl}, \mathrm{pH} 7.4,1 \mathrm{mmol} / \mathrm{L} \mathrm{NaHCO}_{3}$ and by homogenizing with a Polytron (Kinematica, Littau, Switzerland) at $4^{\circ} \mathrm{C}$, setting 6 for $3 \times 20$ sec. The homogenate was diluted (1:1) with $50 \mathrm{mmol} / \mathrm{L}$ Tris- $\mathrm{HCl}, \mathrm{pH} 7.4,1 \mathrm{mmol} / \mathrm{L}$ EDTA, $1 \mathrm{mmol} / \mathrm{L} \mathrm{MgCl}_{2}$ and sedimented at $30,000 \mathrm{~g}$ for $15 \mathrm{~min}$ at $4^{\circ} \mathrm{C}$. The pellet was washed once and resuspended in 50 $\mathrm{mmol} / \mathrm{L}$ Tris- $\mathrm{HCl}, \mathrm{pH} 7.4,250 \mathrm{mmol} / \mathrm{L}$ sucrose. The membranes were frozen and stored at $-70^{\circ} \mathrm{C}$. Protein concentration was determined by the method of Lowry et al. (25) using BSA as standard.

Binding Assay. Binding studies were performed in triplicate at $4^{\circ} \mathrm{C}$ for $5 \mathrm{hr}$ in a HEPES buffer, as described elsewhere (13, 26). Incubation volume was $0.5 \mathrm{ml}$. ${ }^{125} \mathrm{I}-\mathrm{rANF}(99-126)$ (Biotrend, Köln, FRG; specific activity $2,200 \mathrm{Ci} / \mathrm{mmol}$ ) concentration was $20 \mathrm{pmol} / \mathrm{L}$. For competitive binding, the unlabeled peptides rANF(99-126) (Novabiochem, Laufelfingen, Switzerland) or des(18-22)-rANF(4-23)- $\mathrm{NH}_{2}$, a truncated ANF analogue that binds to $\mathrm{C}$ receptors only (9), were present in increasing concentrations $\left(10^{-12}\right.$ to $\left.10^{-6} \mathrm{~mol} / \mathrm{L}\right)$. Binding reactions were initiated by adding $15 \mu \mathrm{g}$ of glomerular membrane protein. Reactions were stopped by dilution with $2.5 \mathrm{ml}$ ice-cold $50 \mathrm{mmol} / \mathrm{L}$ Tris- $\mathrm{HCl}, \mathrm{pH} \mathrm{7.4}$, and rapid filtration through $1 \%$ polyethyleneimine-treated Whatman GF/C filters (Whatman, Maidstone, United Kingdom). Filters were washed with $5 \mathrm{ml} 50 \mathrm{mmol} / \mathrm{L}$ Tris- $\mathrm{HCl}$, pH 7.4, allowed to dry and radioactivity was measured in an LKB 1261 Multigamma counter (LKB, Turku, Finland) with $80 \%$ efficiency.

Afinity Cross-linking of ANF Receptors. Thirty micrograms glomerular membrane protein were incubated for $5 \mathrm{hr}$ at $4^{\circ} \mathrm{C}$ with $60 \mathrm{pmol} / \mathrm{L}^{125} \mathrm{I}-\mathrm{rANF}(99-126)$ in the presence or absence of unlabeled rANF(99-126) or of des(18-22)-rANF(4-23)- $\mathrm{NH}_{2}$. After incubation, the membranes were washed, resuspended in ice-cold PBS buffer, pH 7.5, and incubated with $0.1 \mathrm{mmol} / \mathrm{L}$ bis(sulfosuccinimidyl)suberate (Pierce, Beijerland, The Netherlands) for $25 \mathrm{~min}$ at $4^{\circ} \mathrm{C}$. The reaction was quenched by adding $10 \mathrm{mmol} / \mathrm{L}$ ammonium acetate and the membranes were centrifuged in an Eppendorf centrifuge for $7 \mathrm{~min}$. The pellet was resuspended in $30 \mu \mathrm{l}$ sample buffer $(62 \mathrm{mmol} / \mathrm{L}$ Tris- $\mathrm{HCl}$, pH $6.8,2 \%$ SDS, $10 \%$ glycerol, $0.001 \%$ bromphenol blue) containing $5 \% 2$-mercaptoethanol and heated for $3 \mathrm{~min}$ at $100^{\circ} \mathrm{C}$. Membrane proteins were separated on a $7.5 \%$ SDS-PAGE under constant voltage conditions (Hoefer Scientific Instruments, San Francisco, CA). Standard molecular weight markers were used for calculation of molecular weights
TABLE 1. $B_{\text {max }}$ and $K_{D}$ of glomerular ANF binding sites in BDL rats with ascites and in SHAM rats ${ }^{a}$

\begin{tabular}{lcc}
\hline \multicolumn{1}{c}{ Variable } & $\begin{array}{c}\text { SHAM rats } \\
\mathbf{n}=\mathbf{1 0}\end{array}$ & $\begin{array}{c}\text { BDL rats } \\
\mathbf{n}=\mathbf{1 0}\end{array}$ \\
\hline $\begin{array}{l}\text { ANF plasma concentration } \\
\text { (fmol/ml) }\end{array}$ & $7.6 \pm 1.3$ & $8.7 \pm 2.1$ \\
$\begin{array}{l}\text { Total binding sites } \\
\text { (fmol/mg protein) }\end{array}$ & $1,648 \pm 358$ & $3,518 \pm 864^{b}$ \\
B receptor & & \\
$\quad \mathrm{B}_{\max }$ (fmol/mg protein) & $162 \pm 63$ & $58 \pm 11$ \\
$\mathrm{~K}_{\mathrm{D}}$ (pmol/L) & $96 \pm 49$ & $23 \pm 8$ \\
$\mathrm{C}$ receptor & & \\
$\mathrm{B}_{\max }$ (fmol/mg protein) & $1,486 \pm 363$ & $3,460 \pm 866^{b}$ \\
$\mathrm{~K}_{\mathrm{D}}$ (pmol/L) & $693 \pm 175$ & $1,116 \pm 293$ \\
\hline
\end{tabular}

${ }^{a} B_{\max }=$ density; $K_{D}=$ affinity.

${ }^{6}$ Significant difference $(p<0.05)$ to SHAM rats.

of labeled bands (Serva, Heidelberg, FRG). Gels were stained, dried and exposed to Kodak X-OMAT AR film with a Kodak $\mathrm{X}$-OMAT regular enhancing screen (Eastman Kodak, Rochester, NY) at $-70^{\circ} \mathrm{C}$ for 2 to 3 wk.

Analysis of Data. The results are expressed as mean \pm S.E. Binding data were analyzed using the LIGAND program (27) to determine the density and affinity of binding sites from competitive experiments. Data of BDL animals were compared with SHAM controls by Student's $t$ test; a p value of 0.05 or less was considered statistically significant.

\section{RESULTS}

Quantification of ANF Receptor Binding Sites. For the present study only BDL rats with ascites were selected. As shown in Table 1, these animals had similar ANF plasma concentrations as the control rats $(8.7 \pm$ 2.1 vs. $7.6 \pm 1.3 \mathrm{fmol} / \mathrm{ml})$. The biphasic shape of competition binding curves with rANF(99-126), binding to $\mathrm{B}$ and to $\mathrm{C}$ receptors (Fig. 1, upper panel) suggested the presence of two different binding sites. Competition binding with the ANF analogue binding to $\mathrm{C}$ receptors only (Fig. 1, lower panel) showed a monophasic curve, displacing less of the labeled peptide at excess concentrations than $\mathrm{rANF}(99-126)$. Thus there were probably $\mathbf{B}$ and $\mathbf{C}$ receptors present on glomerular membranes, with the majority of the $\mathrm{C}$ type. Analysis of competition binding curves to glomerular membranes (Fig. 1) showed that the total receptor density was significantly increased $(3,518 \pm 864$ vs. $1,648 \pm 358 \mathrm{fmol} / \mathrm{mg}$ protein; $p<0.05$ ) in BDL rats (Table 1). Quantification of both receptor types demonstrated that this increase was due to a significant augmentation of the $\mathrm{C}$ receptor population in the BDL animals $(3,460 \pm 866$ vs. $1,486 \pm 363 \mathrm{fmol} / \mathrm{ml}$ protein; $p<0.05)$. The density of $B$ receptors tended to be decreased, however not significantly so (58 \pm 11 vs. $162 \pm 63 \mathrm{fmol} / \mathrm{mg}$ protein). There was no significant difference in affinity of $B$ or $C$ receptors to $\mathrm{ANF}$ between $\mathrm{BDL}$ and SHAM rats (Table 1).

Molecular Weight Characterization of ANF Binding Sites. The presence of glomerular ANF binding sites was confirmed and their molecular weight characterization was performed by affinity cross-linking studies in SHAM 

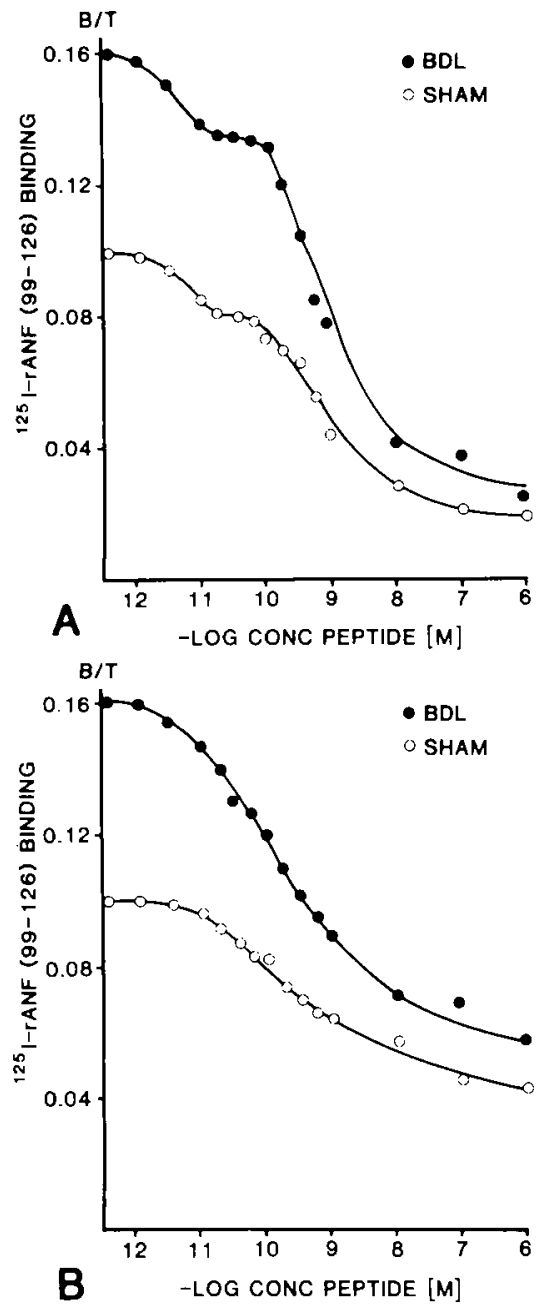

Fig. 1. Representative competition binding curves of ${ }^{125}$ I-rANF to glomerular membranes. Membranes from (-) BDL and (0) SHAM rats were incubated in triplicate with increasing concentrations of unlabeled $\mathrm{rANF}$ (99-126) binding to $\mathrm{B}$ and $\mathrm{C}$ receptors $(\mathrm{A})$ or $\operatorname{des}(18-22)$ rANF(4-23) binding to $C$ receptors only (B). Results are expressed as bound/total vs. total (unlabeled peptide).

and in BDL rats. Autoradiography of the dried gel of glomerular membrane preparations from both BDL rats and controls showed two bands with the apparent molecular weights of $65 \mathrm{kD}$, as reported for the $\mathrm{C}$ receptor, and $130 \mathrm{kD}$, as demonstrated for the $\mathrm{B}$ receptor (Fig. 2A). Displacement with increasing concentrations of unlabeled ANF proved the specificity of ${ }^{125} \mathrm{I}-\mathrm{rANF}$ cross-linking (Fig. 2B). Excess concentrations $\left(10^{-6}\right.$ $\mathrm{mol} / \mathrm{L}$ ) of the truncated analogue, binding to the $\mathrm{C}$ receptor only, displaced the band at $65 \mathrm{kD}$ but not the band at $130 \mathrm{kD}$ (Fig. 2C).

Thus the two ANF binding sites determined under our experimental conditions were most likely identified as B and $\mathrm{C}$ receptors.

\section{DISCUSSION}

In this study, we found an altered density of ANF binding sites on renal glomeruli of cirrhotic rats. Bile

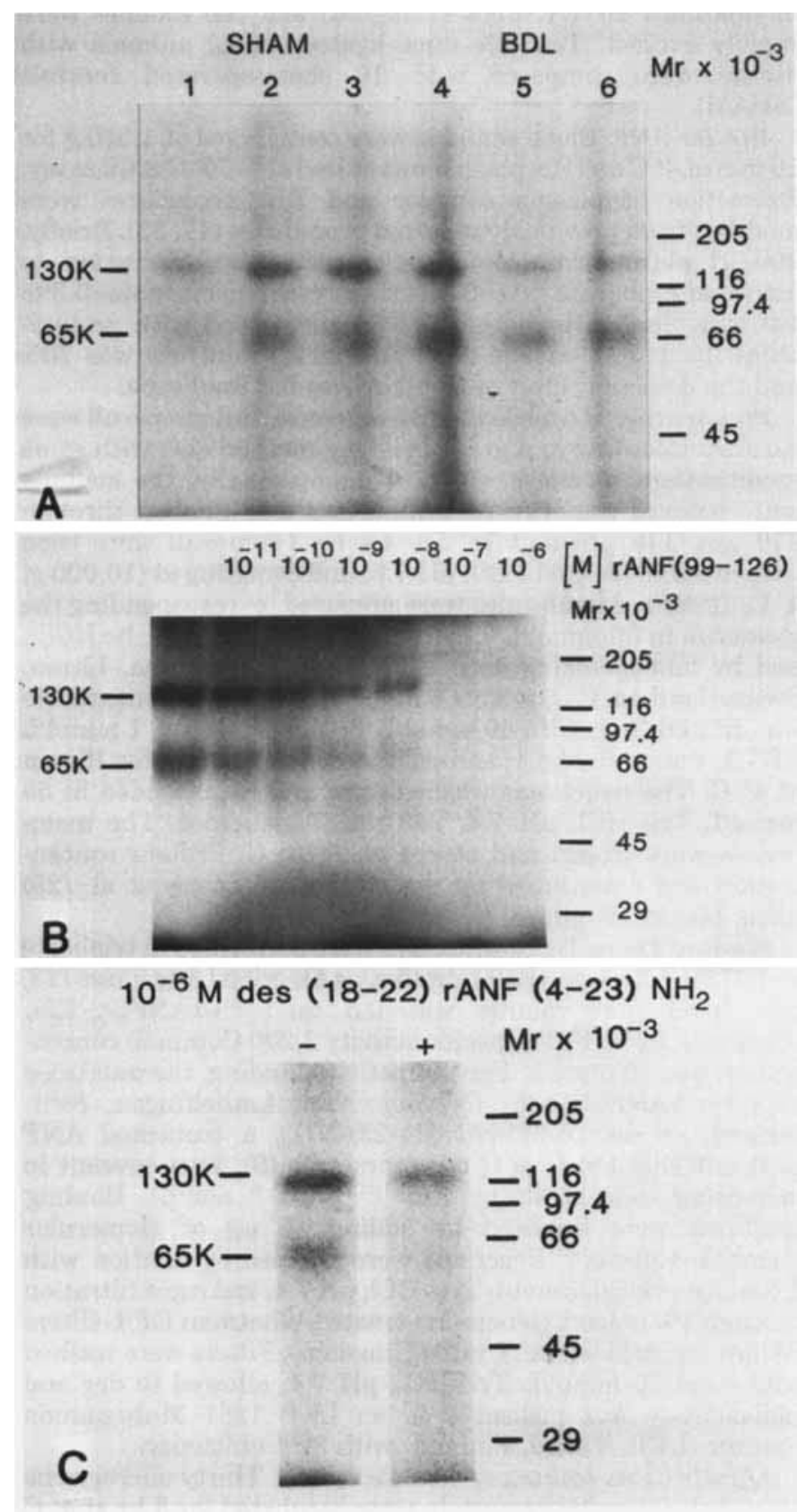

FiG. 2. Autoradiogram of SDS-PAGE-resolved glomerular membrane protein after cross-linking with ${ }^{125} \mathrm{I}$-rANF, which binds to both $\mathrm{B}$ and $\mathrm{C}$ receptors. (A) Labeled bands are at $130 \mathrm{kD}$ and $65 \mathrm{kD}$ (the motilities of molecular weight standards are shown at the right side of the gel) in glomerular membranes from BDL rats (lanes 4 to 6) and SHAM (lanes 1 to 3 ). The bands correspond to the molecular weight of the $B$ receptor $(130 \mathrm{kD})$ and the $C$ receptor $(65 \mathrm{kD})$, respectively. (B) Labeled bands (glomeruli from control rats) at 130 $\mathrm{kD}$ and $65 \mathrm{kD}$ are both displaced with increasing concentrations of unlabeled rANF(99-126), which binds to B and C receptors. This finding demonstrates specific labeling of the bands as ANF binding sites. (C) The band at $65 \mathrm{kD}$, but not the band at $130 \mathrm{kD}$ (glomeruli from control rats), is displaced by $10^{\circ} \mathrm{mol} / \mathrm{L} \operatorname{des}(18-22)$-rANF(423) $-\mathrm{NH}_{2}$, a truncated $\mathrm{ANF}$ analogue that binds to $\mathrm{C}$ receptors only. Altogether these data most likely characterize the binding sites determined as $\mathrm{B}$ and $\mathrm{C}$ receptors. 
duct ligation was chosen as a rat model of cirrhosis; to assure an advanced stage with massive sodium retention, only animals with marked ascites were investigated.

The two types of ANF binding sites, identified on glomerular membranes, most likely correspond to the B and $\mathrm{C}$ receptors. This conclusion is supported by the following observations: (a) Competitive binding curves with the unlabeled ligand ANF(99-126), binding to both receptors, exhibited a biphasic shape and computerized analysis continuously yielded better fits for two than for one binding site. Furthermore, displacement with the truncated analogue, binding to $\mathrm{C}$ receptors only, showed just one class of receptors (Fig. 1). (b) Resolutions of glomerular membranes by SDS-PAGE after crosslinking to ${ }^{125}$ I-rANF showed two specifically labeled bands at $65 \mathrm{kD}$ and $130 \mathrm{kD}$, corresponding to the reported molecular weight of the $\mathrm{C}$ and $\mathrm{B}$ receptor, respectively, with the truncated analogue displacing the $65 \mathrm{kD}$ band only (Fig. 2).

The density of total ANF binding sites was markedly increased in BDL rats compared with controls. These findings are in accordance with the observation of increased glomerular ANF receptor density in BDL rats by Morgan et al. (28). These authors, however, while finding a blunted cGMP generation, did not differentiate ANF receptor types. Discrimination of both ANF receptors showed that the increased receptor density in our experiments was due to a twofold augmented number of $\mathrm{C}$ receptors. B-receptor density was not significantly decreased in BDL rats. The ratio of $\mathrm{B}$ to $\mathrm{C}$ receptors was eminently reduced in BDL animals. Thus a given dose of ANF would be less effective in the kidney of cirrhotic compared with control animals: the proportion of ANF reaching the $B$ receptors would be reduced; moreover, the number of $B$ receptors, linking ANF to its biological effects, tended to be decreased.

Because the changes of density of ANF receptors in cirrhosis were accompanied by a tendency of inverse alterations of affinity, there might be doubts about the biological net result of these changes. However, several observations are against such an interpretation: Reciprocal changes of binding capacity and affinity of ANF to glomeruli have often been described $(11,12,29)$ (e.g., a 3.5-fold increase of receptor density after a low salt diet accompanied by a 2.5 -fold decrease of affinity) (10). Contrary to the hypothesis that this lowering of the affinity would tend to oppose the augmented receptor density, greater ANF binding was observed in this group of animals at any given ANF concentration (10). Thus, it seems that changes in receptor density outweigh changes in affinity. Furthermore, to eliminate possible influences of affinity on the calculated receptor density, we additionally performed a simultaneous fit of the binding data of both groups and calculations with the same, shared affinity for all animals with the LIGAND program (27). Both approaches yielded similar results as those generated by individual fits shown in Table 1 . Thus using various analytical procedures, C-receptor density was constantly found to be significantly augmented in cirrhosis.

Why was glomerular density of ANF receptors changed in the cirrhotic rats? Because little information is available on the regulation of $B$ and $C$ receptors for ANF by physiological stimuli and this is the first communication about the influence of a pathophysiological condition on the ANF receptor status, the question can hardly be answered. Increased density of glomerular ANF binding sites has been observed on dehydration or low salt diet (10-12). We could recently demonstrate that dehydration selectively increases $C$ receptors with no effect on B-receptor density (13). This change was accompanied by a decrease of ANF plasma concentration. In the present investigation, however, cirrhotic rats exhibited increased C-receptor density at ANF plasma concentrations not different from those of control rats. Therefore changes of ANF receptor density in the BDL animals cannot be explained by different concentrations of circulating ANF. Thus expression of glomerular ANF receptors is altered in cirrhosis by a mechanism that remains to be elucidated.

Actually, renal response to endogenously released and to exogenously administered ANF is blunted in cirrhosis (for review see references 30 and 31). Several factors, such as a decrease of blood pressure or an activation of sodium-retaining systems after the administration of ANF, might be involved therein $(18,20,32)$. However, as demonstrated by our study, alterations of renal ANF receptor density might also contribute to the renal resistance to ANF. The present investigation, for the first time quantitatively determining renal $B$ and $C$ receptors for ANF in a pathophysiological state, shows an increased number of clearance receptors in the BDL model of cirrhosis. Thus alterations of renal ANF binding sites indeed could contribute to the observed resistance to ANF in cirrhosis.

Acknowledgments: The technical assistance of $\mathrm{M}$. Bauch, M. Hummel, M. Raab and $H$. Sägesser is gratefully acknowledged. We wish to thank Dr. R.M. Arendt for providing antibody Toni III, Dr. A. DeLéan for helpful discussions and Dr. P. J. Munson for clarification of data analysis.

\section{REFERENCES}

1. Arendt RM, Gerbes AL. Atrialer natriuretischer Faktor: die endokrine Funktion des Herzens. Dtsch Med Wschr 1986;111: 1849-1857.

2. Cantin M, Genest J. The heart as an endocrine gland. Sci Am 1986;254:76-81.

3. Lang RE, Unger T, Ganten D. Atrial natriuretic peptide: a new factor in blood pressure control. J Hypertens 1987;5:255-271.

4. Needleman PJ, Greenwald JE. Atriopeptin: a cardiac hormone intimately involved in fluid, electrolyte, and blood-pressure homeostasis. N Engl J Med 1986;314:828-834.

5. Thibault G, Garcia R, Gutkowska J, Genest J, Cantin M. Atrial natriuretic factor: a newly discovered hormone with significant clinical implications. Drugs 1986;31:369-375.

6. Almeida FA, Suzuki M, Scarborough RM, Lewicki JA, Maack T. Clearance function of type $\mathrm{C}$ receptors of atrial natriuretic factor in rats. Am J Physiol 1989;256: R469-R475. 
7. Chinkers M, Garbers DL, Chang MS, Loewe DG, Chin H, Goeddel DV, Schulz S. A membrane form of guanylate cyclase is an atrial natriuretic peptide receptor. Nature $1989 ; 338: 78-83$.

8. De Léan A, Vinay $P$, Cantin $M$. Distribution of atrial natriuretic factor receptors in dog kidney fractions. FEBS Lett 1985;193: 239-242.

9. Maack T, Suzuki M, Almeida FA, Nussenzveig D, Scarborough RM, McEnroe GA, Lewicki JA. Physiological role of silent receptors of atrial natriuretic factor. Science 1987;238:675678.

10. Ballermann BJ, Hoover RL, Karnovsky MJ, Brenner BM. Physiologic regulation of atrial natriuretic peptide receptors in rat renal glomeruli. J Clin Invest 1985;76:2049-2056.

11. Gauquelin G, Thibault G, Cantin M, Schiffrin EL, Garcia R. Glomerular atrial natriuretic factor receptors during rehydration: plasma $\mathrm{NH}_{2}$ - and $\mathrm{COOH}$-terminal levels. Am J Physiol 1988;255: F621-F625.

12. Gauquelin G, Garcia R, Carrier F, Cantin M, Gutkowska J, Thibault G, Schiffrin EL. Glomerular ANF receptor regulation during changes in sodium and water metabolism. Am J Physiol 1988;254:F51-F55.

13. Kollenda MC, Vollmar AM, McEnroe GA, Gerbes AL. Dehydration increases the density of C-receptors for ANF on rat glomerular membranes. Am J Physiol 1990;258:R1084-R1088.

14. Olivera A, Gutkowska J, Rodriguez-Puyol D, Fernandez-Cruz A Lopéz-Novoa JM. Atrial natriuretic peptide in rats with experimental cirrhosis of the liver without ascites. Endocrinology 1988; 122:840-846.

15. Gines P, Llach J, Tito L, Jiménez W, Badalamenti S, Salmerón JM, Toledo C, et al. Mechanism of the blunted renal response to atrial natriuretic factor (ANF) in cirrhotics with ascites: evidence against a role of impaired systemic hemodynamics [Abstract]. J Hepatol 1989;9(Suppl.1):S37.

16. Gerbes AL, Arendt RM, Stangl E, Gülberg V, Sauerbruch T, Jüngst D, Paumgartner G. Characterization of the ANF system in patients with cirrhosis of the liver. In: Forssmann WG, Scheuermann DW, Alt J, eds. Functional morphology of the endocrine heart. Darmstadt: Steinkopff, 1988:229-234.

17. Gerbes $A L$, Wernze $H$, Arendt RM, Riedel A, Sauerbruch $T$, Paumgartner G. Atrial natriu retic factor and renin-aldosterone in volume regulation of patients with cirrhosis. HePatolocy 1989;9: 417-422.

18. Laffi G, Pinzani M, Meacci E, La Villa G, Renzi D, Baldi E Cominelli $E$, et al. Renal hemodynamic and natriuretic effects of human atrial natriuretic factor infusion in cirrhosis with ascites. Gastroenterology 1989;96:167-177.

19. Panos M, Gove C, Firth J, Raine A, Ledingham J, Westaby D, Williams $R$. Resistance to the natriuretic action of atrial natriuretic peptide on the isolated kidney of rats with experimental cirrhosis [Abstract]. J Hepatol 1989;9(Suppl.1):S70.

20. Petrillo A, Scherrer U, Gonvers JJ, Nussberger J, Marder H, de Vane $P$, Waeber B, et al. Atrial natriuretic peptide administered as intravenous infusion or bolus injection to patients with liver cirrhosis and ascites. J Cardiovasc Pharmacol 1988;12:279-285.

21. Salerno F, Badalamenti S, Incerti P, Compozza L, Mainardi L. Renal response to atrial natriuretic peptide in patients with advanced liver cirrhosis. Hepatology 1988;8:21-26.

22. Kountouras J, Billing BH, Scheuer PJ. Prolonged bile duct obstruction: a new experimental model for cirrhosis in the rat. $\mathrm{Br}$ $J$ Exp Pathol 1984;65:305-311.

23. Arendt RM, Gerbes AL, Ritter D, Stangl E. Molecular weight heterogeneity of plasma-ANF in cardio-vascular disease. Klin Wochenschr 1986;64(Suppl.VI):97-102.

24. Misra RP. Isolation of glomeruli from mammalian kidneys by graded sieving. Am J Clin Pathol 1974;58:135-139.

25. Lowry $\mathrm{OH}$, Rosebrough NJ, Farr AL, Randall RJ. Protein measurement with the folin phenol reagent. J Biol Chem 1951; 193:265-275.

26. Kollenda MC, Scarborough RM, Gerbes AL. Discrimination and quantification of glomerular receptor subtypes for atrial natriuretic factor (ANF). J Receptor Res, 1991; in press.

27. Munson PJ, Rodbard D. LIGAND: a versatile computerized approach for characterization of ligand-binding systems. Anal Biochem 1980;107:220-239.

28. Morgan TR, Morgan K, Jonas GM, Thallai I. Increased glomerular atrial natriuretic peptide (ANP) receptor number following bile duct ligation (BDL) [Abstract]. Gastroenterology 1990;98:A612.

29. Garcia R, Gauquelin G, Cantin M, Schiffrin EL. Glomerular and vascular atrial natriuretic factor receptors in saralasin sensitive and -resistant two-kidney, one clip hypertensive rats. Circ Res 1988;63:563-571.

30. Epstein M. Atrial natriuretic factor in patients with liver disease. Am J Nephrol 1989:9:89-100.

31. Gerbes AL, Arendt RM, Paumgartner G. Atrial natriuretic factor: possible implications in liver disease [Editorial Review]. J Hepatol 1987;5:123-132.

32. Gerbes AL. Augmentation of the natriuretic response to atrial natriuretic factor in cirrhosis. HePatology 1989;10:897-898. 